Article

\title{
The Impact of the Entrepreneurship Promotion Programs and the Social Networks on the Sustainability Entrepreneurial Motivation of Engineering Students
}

\author{
Catalina Rus-Casas ${ }^{1}\left(\mathbb{D}\right.$, Dolores Eliche-Quesada ${ }^{2} \mathbb{C}$, Juan D. Aguilar-Peña ${ }^{1} \mathbb{(}$, \\ Gabino Jiménez-Castillo ${ }^{1}$ (D) and M. Dolores La Rubia ${ }^{2, *(D)}$ \\ 1 Department of Electronics and Automatics Engineering, Campus Las Lagunillas, University of Jaén, \\ 23071 Jaén, Spain; crus@ujaen.es (C.R.-C.); jaguilar@ujaen.es (J.D.A.-P.); gjimenez@ujaen.es (G.J.-C.) \\ 2 Department of Chemical Environmental and Materials Engineering. Campus Las Lagunillas, \\ University of Jaén, 23071 Jaén, Spain; deliche@ujaen.es \\ * Correspondence: mdrubia@ujaen.es; Tel.: +34-953212920
}

Received: 21 May 2020; Accepted: 15 June 2020; Published: 17 June 2020

check for updates

\begin{abstract}
This paper presents the results of three academic courses in which Entrepreneurship Promotion Programs (EPP) have been developed for engineering students at the University of Jaén. This study describes the activities and how they have been promoted using the social networks Facebook and Twitter. Grytics for Analytics software was used for monitoring Facebook activity. The use of these tools has also allowed the collaborative development of the Engineering degree competencies related to sustainability and entrepreneurship through the Materials Science disciplines. The study is based on questionnaires before and after the EPP which involved a sample of 459 engineering students. The Kaiser-Meyer-Olkin test, Kolmogorov-Smirnov test and Pearson's correlation were used. The questionnaires show which factors have the strongest influence on the intention to undertake entrepreneurial activity. Motivation (MO), personal requirements (PR), perception of the environment (PE) and the background requirements (BR) were the factors considered. The statistical study shows that PE and PR have a strong influence on MO. Finally, through the study before and after the EPP, the success of the activities and the use of social networks have been demonstrated. The results indicate that the activities of the EPP influence the perception of the environment and the motivation of the engineering students. However, the personal requirements are not affected by the activities.
\end{abstract}

Keywords: entrepreneurial motivation; sustainability entrepreneurship; social networks; Facebook; Twitter

\section{Introduction}

The characteristics of the new labor market and the changes in personal orientations towards work suggest that self-employment and small businesses will be increasing in our environment [1]. For this reason, university level education must be completed with some transferable skills that make the training of the students more efficient in this area [2,3].

Entrepreneurship is a transversal competence in the Engineering degree's "CT3- Entrepreneurship capacity and entrepreneurial culture". A transversal competence refers to the skills that are important to graduates across all disciplines. This competence contributes not only to the creation of new companies, but also to the employability of young people [4]. The European Commission recognizes entrepreneurial education as a tool that can help young people not only to learn how to run a 
business, but to develop many skills related to this area. Entrepreneurship is at the heart of innovation, productivity growth, competitiveness, economic growth and job creation [5].

Engineering students are often predisposed to innovation and product development and are therefore closely related to entrepreneurship. But it is necessary to guide and motivate them so that they acquire this competence and are able to identify opportunities in their professional field [6].

On the other hand, in some disciplines within the Engineering degree, the specific competence "CC10-Basic knowledge and application of environmental technologies and sustainability" is gathered. However, given its relevance, it should be developed as a transversal competence throughout Engineering degrees. Therefore, it must be a priority issue, and a sustainability target could be developed together with other competencies in a real and applied way. In this sense, the CC10 and CT3 competencies could be linked in the concept of sustainable entrepreneurship.

Sustainable entrepreneurship is carried out from an ethical, conscientious and social perspective. Business sustainability is a balance between wealth creation and a sustainable use of resources. For this, it is important to generate a positive impact on the environment by integrating environmental and social gains from applying policies for resource efficiency. Furthermore, it must be achieved from an ethical attitude focused on societal benefits; in other words, attracting human talent, working as a team, implementing the corresponding legislation on human rights, and championing inclusion policies. All this seeks a positive balance that provides continuity in the market [7].

An important teaching/learning challenge to improve skill acquisition such as entrepreneurship and sustainability in a transversal way it is the incorporation of new methodologies that favor the development of these competencies in a dynamic and attractive way [8].

Currently, social networks are integrated into our daily life as a way of communication in certain fields. In the educational field, they can be used to enhance communication between groups of people, make them feel part of a community and cooperate with each other in common tasks. In addition, they are excellent tools for breaking the space-time barriers as well as the boundaries of current educational systems [9]. This fact offers an opportunity to integrate social networks as a way of training at the university level [10]. However, social networks remain rarely used in the academic field because they are perceived as social and not formative tools. The studies conducted on the use of social media in higher education are currently very limited and contradictory [11].

However, the contribution of social media could be important since they allow collaborative work, which is a methodology based on the exchange and development of knowledge by small groups of peers focused on academic outputs. In addition, collaboration increases motivation and promotes the teaching/learning process and critical thinking, which are important skills for graduating from university [2,12].

In this situation, the use of social networks can play an important role in promoting sustainable entrepreneurship in order to improve motivation, collaboration, and the exchange of information with contact with experts. They can become new business or commercial opportunities that also make possible a balance between wealth creation and the sustainable use of resources in our environment [13-15].

Currently, many Entrepreneurial Promotion Programs (EPP) are being developed with the aim of implementing activities to promote entrepreneurial spirit among university students. These programs have been consolidated as an essential resource to promote the skills that contribute to self-employment among young people. The use of the social networks in these programs can provide new tools of great utility for the development of the skills which promote the business activity. On the other hand, many EPPs have been designed to address entrepreneurship activities as class work, so can be combined with the development of other competencies such as those related to sustainability.

This paper describes the activities of EPPs, and the tools used, during three academic years in the Engineering degree at the University of Jaén. The activities were proposed during the development of the disciplines of the Materials Science and Metallurgical Engineering area, and they encompass the transversal competence "CT3" related to entrepreneurial spirit and the specific competence "CC10" related to sustainability. Social networks were used to promote the sustainability entrepreneurship. 
In addition, we evaluated the impact of the use of social networks and their influence on the factors that affect the entrepreneurial spirit of the engineering students.

\section{Theoretical Background and Hypotheses}

\subsection{Factors Influencing Entrepreneurial Spirit}

When developing entrepreneurship programs, many authors consider it highly important to understand the factors that influence the intentions of entrepreneurs [16-20]. This is because the success in creating a new company depends fundamentally on the entrepreneur who uses his/her resources to work on his/her own. Many factors play a role in entrepreneurial behavior; they consist of a combination of personal factors, attributes, experience, disposition, and perceptions, etc. [21-24]. In general, entrepreneurial intentions are guided by the individual's attitude toward entrepreneurship, by motivation, personal characteristics, as well as external factors (social norms, financial, economic, or legal factors) [25-30].

The motivation to undertake is a very important factor, and is described as the psychological process by which someone sets a goal, uses the appropriate means, and maintains the standards of behavior in order to achieve that goal [31]. Several models have been developed to explain how entrepreneurial intention is based on the voluntary and conscious decisions of the entrepreneur in which external factors have influenced [32,33]. Actually, when considering the motivation, factors of different nature are included. In many cases, a distinction is made between entrepreneurs who launched their business by opportunity, when the individual considers it as a source of profit, or by necessity, when the individual opts for entrepreneurship because they cannot find what they are looking for in the job market [34,35].

Among the personal factors, there are many qualities that support this undertaking. However, self-efficacy is considered of great importance at the beginning of a business project [36-38]. This concept presents different approaches, depending on whether it is considered exclusively as the belief in the ability to succeed or whether it is considered to be affected by external factors [37,39]. From any of these perspectives, the recognition of entrepreneurial qualities supports the identification of opportunities and can drive towards entrepreneurship. Furthermore, this perception can be improved through courses and programs to promote entrepreneurial culture that develop these skills [40-44].

Aspects related to the environment are also widely studied in the literature, due to their influence on entrepreneurial intention. The environment can positively influence entrepreneurial intention depending on family support, business level in the region, social norms, cultural level or business education [45]. Unfortunately, it is in the environment where the main obstacles to undertaking exist. Limiting factors include difficulties in obtaining financing, the tax system, administrative complexity, the protection of property rights, the level of confidence, political and economic stability, and the valuation that society makes of entrepreneurship, among others [46]. Individual values allow many cases to be undertaken despite the adversities of the environment [47].

The environment will also be crucial to promote sustainable entrepreneurship, since entrepreneurs will not only attend to economic benefits and sustainable entrepreneurs include in the business model that they design sustainability challenges [48]. It is a fact that it is increasing the number of companies that attach great value not only to the economic impact, but also sustainability and environment protection. Therefore, the sustainable business opportunities can be identified as a need of the environment in which we find ourselves and, if the entrepreneurs incorporate these qualities into the business, the products generated will have an added value $[48,49]$. The opportunities of the sustainable entrepreneur will depend on the level of the commitment to sustainability that the business acquires and the environmental risks of the idea or product.

Sustainable companies have understood that they have to be identified by their commitment to mitigate environmental damage, and they are adapting to environmental changes, thereby contributing to more sustainable development [48]. However, for young people, a precondition for this behavior 
change towards sustainability "is recognizing that there is a serious problem" [49]. For that reason, training in environmental risks is important for young people because it increases awareness of climate change and, in this way, can this influence the cognitive processes that lead to sustainable business intent.

\subsection{Entrepreneurial Promotion Programs}

Today, entrepreneurship education is vital in many aspects because it can influence different important factors [4]. The methodologies used in these programs are varied and they are constantly evolving towards a form that guarantees good results [50].

At the European level, the European Commission establishes that at least one practical entrepreneurship program must be incorporated during elementary education [51].

In Spain, the Law 14/2013 of 27 September 2013 to support entrepreneurs and their internationalization [52] promotes university entrepreneurship initiatives to bring young university students closer to the business world. It urges universities to encourage the initiation of business projects, providing information and help to students, as well as promoting meetings with entrepreneurs.

At the regional level, there are two regulations which try to make this objective effective, the Law 3/2018 of 8 May of Andalusian Promotion of Entrepreneurial Culture in the Andalusian Public System (BOJA), which approved the "Plan for the Promotion of Entrepreneurial Culture in the Andalusian Public System" (BOJA No. 137 of 14 July 2011), and the Decree-Law 8/2013 of 28 May, "Measures To Create Employment and Promote Entrepreneurship" (BOJA of 31 May 2013) [53,54].

The University of Jaén is participating in these initiatives with measures endorsed in the "Practical Training Plan for Employability at the University of Jaén" and the "Support Plan for the Transfer of Knowledge, Entrepreneurship and Employability (2018-2019)" [55,56].

The main objective of these plans is promoting entrepreneurial spirit, self-employment and the creation of companies that offer innovative services among students. To do this, they propose multidisciplinary collaboration between teachers of different degrees, courses, and fields to implement projects. These projects promote understanding of the services, agents, and entrepreneur programs of the university and institutions, as well as the role of the science-technology parks and technology centers in the region. On the other hand, they promote collaboration between teachers and companies in the region.

However, after several editions of these programs, it is necessary to evaluate the impact of the programs in the promotion of the entrepreneurial spirit among students [57].

\subsection{Social Networks, Education and Entrepreneurship}

In recent years, social networks have influenced the way of communicating and interacting of the internet users. They are a key tool to keep in contact with friends, family and colleagues. They also allow people with similar professional interests to connect, establish working relationships, and share knowledge and information. Social networks have sparked a revolution in the field of interrelationships in recent years, but they are not often found in the academic field [12].

To date, many social networks are operating in satisfactory manner. Horizontal social networks are remarkable because they have no defined theme, they are aimed at a generic audience and they are focused on keeping people in contact (Facebook, Twitter, Google+, etc). On the other hand, the specialized or vertical social networks have a specialization established according to different parameters, such as the topic on which they are focused (LinkedIn, ResearchGate, Digster), the activity (Second Life, Foursquare) or by the type of media they share (YouTube, Pinterest, SlideShare).

Popular sites such as Facebook, Myspace, Twitter, and LinkedIn offer the possibility of interacting and they also open up the possibility of innovation in the field of didactics. In this sense, it seems undoubted that social networks support, at least, new learning opportunities, especially if we take into account the theories that highlight the student as the center of the teaching/learning process in which they participate actively, instead of being a simple recipient of information [58]. 
The use of social networks as an educational tool can improve motivation, collaboration and communication, breaking down time and space barriers [9]. These tools allow students to provide mutual support in a specific and original way, which is very difficult in the student-teacher relationship. In this way, social networks can be a useful support in the teaching-learning process in university education [11].

Besides, few investigations exist in this area, and lecturers perceive the new technologies with suspicion because they are used by young people for entertainment (SMS, chats, Facebook, YouTube) and that could be a substantial barrier to incorporating them into traditional education $[59,60]$.

Regarding its use related to entrepreneurship, in recent years the use of social networks by entrepreneurs has gone beyond marketing, and they are now used in business networks, information searches, and crowdfunding for businesses. This has given rise to a significant impact, with better company performance and improved innovation results. Related to social networks and entrepreneurship, the literature is scarcer, and most articles investigate the factors that drive the adoption and use of social networks by entrepreneurs [61]. However, there is a growing interest in carrying out more research in this area.

\subsection{Hypothesis}

For all of the above, several factors affecting sustainable entrepreneurship will be defined in this work, among them: motivation (MO) defined as the reasons for undertaking, personal requirements (PR) that encompass entrepreneurial self-efficiency, the perception of the environment (PE), and academic and business training (BR). Based on these factors, the following hypotheses are proposed and are going to be corroborated:

Hypothesis 1. The perception that students have of the environment (PE) has a great impact on the motivation to undertake (MO).

The aim is to verify that the environment of the students influences the reasons for undertaking. In this case, the family environment will be considered, as well as the perceived context, such as social norms, social financial environment, the market, and the help provided to undertake, etc.

Hypothesis 2. The personality-related requirements that the student believes are important for entrepreneurship (PR) have a great impact on students' motivation to undertake (MO).

In this hypothesis, it is proposed that the student's perception of their qualities may affect the reasons for undertaking.

Finally, a third hypothesis is proposed in order to evaluate the effect of the activities of the Entrepreneurship Promotion Programs and the social networks used to promote sustainable entrepreneurship.

Hypothesis 3. The Entrepreneurship Promotion Programs and social networks have a positive impact on the factors that influence sustainable entrepreneurship.

\section{Methodology}

In this work, the results of three academic courses of Entrepreneurship Promotion Programs activities aimed at students of the bachelor's degree in Industrial Engineering at the University of Jaén are presented. A total of 459 students participated in these activities who have attended disciplines of the Materials Science and Metallurgical Engineering area (Materials Science and Engineering, a compulsory discipline in the second year of the bachelor's degree in Industrial Engineering and Materials Technology, a compulsory discipline for the third year of the degree in Industrial Engineering). The transversal CT3 competence, "Entrepreneurship capacity and entrepreneurial culture" of the Engineering degree 
and the generic CC10 competence, "Basic knowledge and application of environmental technologies and sustainability" of the disciplines in the Materials Science and Metallurgical Engineering area have been developed with the activities. Professors from the Department of Chemical Environmental and Materials Engineering and the Department of Electronics and Automatics Engineering of the University of Jaén also participated in these activities.

\subsection{General Scheme}

The study used two questionnaires. The first one was related to entrepreneurship and it was completed by the students before the activities began. In this first questionnaire, students were asked about the factors that influence entrepreneurial intention (Appendix A). The second questionnaire contained questions about the use of social networks (Appendix B). Over three academic years, several activities have been developed both in class and through social networks to promote entrepreneurship and sustainability. In order to understand the impact of these activities on the entrepreneurial spirit of the students, the first questionnaire was carried out again when all the activities had finished (Appendix A). Figure 1 shows a general scheme of the methodology used in this study.

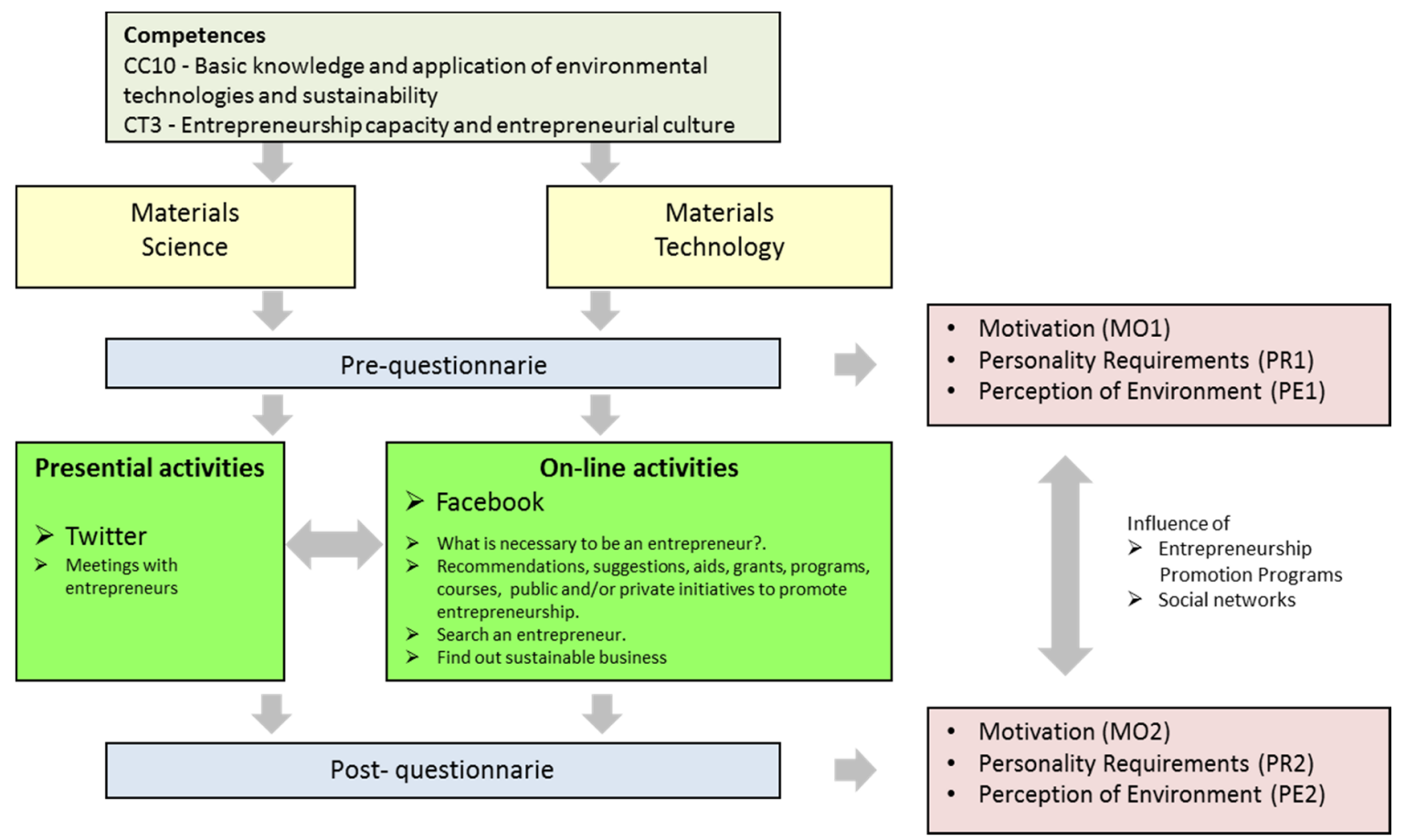

Figure 1. General scheme of the methodology used in this study.

\subsection{Activities and Use of the Social Networks}

The activities focused on two of the objectives of the Entrepreneurship Promotion Programs of the University of Jaén:

- Disseminate and publicize the different agents, services, and resources for entrepreneurship that are available to any entrepreneur;

- Introduce the existence of science-technology parks and technology centers.

The presential and non-presential activities have been established to work on entrepreneurship and sustainability skills. Throughout the semester, in the classrooms, the professors proposed the activities and the students have participated presentially and virtually using Facebook and Twitter. 
As presential activities, several meetings with staff from the Andalusian Entrepreneurship Centers, young entrepreneurs and representatives of the technology centers were organized. Social networks were also used to promote these activities.

Before these meetings with young entrepreneurs, the Twitter account \#eeps_mesa @emprendeepsjaen was created and the students took part of an informative session with the objective to explain how the activities were going to be developed and the details of the use of Twitter.

During the activities, the students were encouraged to follow the account and give their opinion on the interventions of the speakers in real time. Twitter data were used to assess the usefulness of the meetings between entrepreneurs and the engineering students. In addition, the students were asked about the use of Twitter and the personal skills they have identified as important to be an entrepreneur.

Online activities were organized through a closed Facebook group. In the Facebook group, work guidelines were established, and themes related to entrepreneurship and sustainability were assigned by groups of students. Students were encouraged to share interesting links, articles, and news on the proposed topics.

The software Grytics for analytics was used for monitoring the Facebook activity. This tool helped to analyze the participation in the Facebook group. The activity of the group was measured as the number of likes, posts, comments, and visits. In relation to the posts, a wide vision of all the messages was obtained and the participation generated by the members with each message. In addition, the number of the actions of each member was also measured. This way, it was possible to establish the best "likers", the most influential members of the group and those who participated the least. Key performance indicators (KPI) were also determined by Grytics for monitoring actions. Thus, the information of the total activity of the group (number of posts + number of reactions + number of shares)/number of days (120 days)), the group engagement $(2 \times$ number of comments + number of reactions + number of shares)/number of posts) and the engagements rate (number of comments + number of reactions + number of shares) $\times 100$ /number of posts/active members) were collected.

\subsection{Statistical Study and Factor Analysis}

In the statistical study, the IMB SPSS Statistics Version 25 and Microsoft Excel 2013 software were used. From the questionnaire related to entrepreneurship, we studied which questions were grouped in some characteristic way. For this, a factor analysis was applied to the students' answers to find groups of variables with common meaning (factors) and to reduce the number of dimensions necessary to explain the information. In this case, it has been considered that all the variables were independents. The Kaiser-Meyer-Olkin (KMO) test was used to establish whether the grouping of variables was adequate, defining a statistical level greater than 0.6 as acceptable. The explained variance of each factor was used to measure the amount of information that was incorporated to each factor [62]. Table 1 shows the descriptive statistics of the questionnaire variables and the variables of each factor, which correspond to each of the questionnaire questions (Appendix A). The number of factors considered was four. 
Table 1. Descriptive statistics and factors obtained from the variables of the questionnaire questions.

\begin{tabular}{|c|c|c|c|c|}
\hline & \multicolumn{3}{|c|}{ Descriptive Statistics } & \multirow{2}{*}{ Factor } \\
\hline & Variable & Mean & Deviation & \\
\hline V1 & Achieve economic independence & 4.18 & 0.888 & \multirow{9}{*}{ Motivation (MO) } \\
\hline V2 & Personal development & 4.39 & 0.792 & \\
\hline V3 & Labor independence & 4.07 & 0.934 & \\
\hline V4 & Work on what interests you & 4.31 & 0.889 & \\
\hline V5 & Manage your own time & 3.75 & 1.013 & \\
\hline V6 & Need & 3.50 & 0.996 & \\
\hline V7 & Starting a business & 3.72 & 1.047 & \\
\hline V8 & Monetary capital & 3.43 & 1.131 & \\
\hline V9 & Higher incomes & 3.69 & 1.046 & \\
\hline V1 & To be creative & 4.42 & 0.777 & \multirow{5}{*}{$\begin{array}{c}\text { Personality } \\
\text { Requirements (PR) }\end{array}$} \\
\hline V2 & Organizational capacity & 4.37 & 0.764 & \\
\hline V3 & Self confidence & 4.61 & 0.710 & \\
\hline V4 & Take into account all possible situations & 4.20 & 0.791 & \\
\hline V5 & An original and innovative idea & 4.32 & 0.825 & \\
\hline V1 & Business knowledge & 4.10 & 0.834 & \multirow{2}{*}{$\begin{array}{c}\text { Background } \\
\text { Requirements (BR) }\end{array}$} \\
\hline $\mathrm{V} 2$ & Academic background & 3.97 & 0.955 & \\
\hline V1 & Find the right place in the market & 4.22 & 0.741 & \multirow{5}{*}{$\begin{array}{l}\text { Perception of the } \\
\text { Environment } \\
\text { (PE) }\end{array}$} \\
\hline V2 & Economic/financial support & 4.21 & 0.756 & \\
\hline V3 & Infrastructure & 3.81 & 0.871 & \\
\hline V4 & Support from personal environment & 4.06 & 0.830 & \\
\hline V5 & Seek advice on the unknown & 4.32 & 0.736 & \\
\hline
\end{tabular}

Table 2 shows the values obtained in the Kaiser-Meyer-Olkin test, which indicates whether it is appropriate to group the variables or not.

Table 2. Kaiser-Meyer-Olkin (KMO) test values and variances.

\begin{tabular}{ccccc}
\hline Factor & MO & PR & BR & PE \\
\hline KMO & 0.905 & 0.872 & 0.500 & 0.862 \\
Variance $(\%)$ & 90.928 & 90.443 & 96.733 & 90.223 \\
\hline
\end{tabular}

A KMO value equal or greater than 0.6 and a variance equal or greater than $60 \%$ would indicate that the variables are a factor.

From the results, the variables are grouped to form three factors: Motivation (MO), Personality Requirements (PR) and Perception of the Environment (PE). Background Requirements (BR) did not obtain a significant value in the KMO test. These three factors had no multiple collinearity between them (Table 3).

Table 3. Values obtained from the factors.

\begin{tabular}{ccc}
\hline Factor & Mean & Deviation \\
\hline MO & 3.894 & 0.927 \\
PR & 4.387 & 0.736 \\
PE & 4.124 & 0.746 \\
\hline
\end{tabular}

The Kolmogorov-Smirnov test was performed to measure the degree of agreement between the distribution of a data set and a specific theoretical distribution, and therefore it was used to determine the normality of the sample [63]. The results of the Kolmogorov-Smirnov test (Table 4) indicated that all the values obtained a level of significance less than 0.01 . Therefore, the factors did not follow a normal distribution. This fact is important in relation to the temporal study that has been carried out in this work. 
Table 4. Results of the Kolmogorov-Smirnov test.

\begin{tabular}{cccc}
\hline Factor & Statistic & N & Sig. \\
\hline MO & 0.137 & 459 & 0.006 \\
PR & 0.205 & 459 & 0.004 \\
PE & 0.168 & 459 & 0.006 \\
\hline
\end{tabular}

For the verification of the hypotheses, Pearson's linear correlation method (bivariate correlations) was used (Table 5).

Table 5. Pearson correlation coefficients.

\begin{tabular}{|c|c|c|c|c|}
\hline & Factors & MO & PE & PR \\
\hline \multirow{2}{*}{$\mathrm{MO}$} & Pearson Correlation & 1 & - & - \\
\hline & Sig. (bilateral) & - & - & - \\
\hline \multirow{2}{*}{$\mathrm{PE}$} & Pearson Correlation & 0.968 & 1 & - \\
\hline & Sig. (bilateral) & 0.001 & - & - \\
\hline \multirow{2}{*}{ PR } & Pearson Correlation & 0.962 & 0.931 & 1 \\
\hline & Sig. (bilateral) & 0.002 & 0.003 & - \\
\hline
\end{tabular}

Once the relationships between the factors were verified, the results of the questionnaires were compared at two different points in time, before and after the activities. As the factors had a normal distribution, the Wilcoxon test was carried out.

\section{Results}

\subsection{Sample Data}

This study was carried out at the University of Jaén, which is a medium-sized public university located in Jaén (Spain). It has around 16,000 students and offers bachelor's and master's Engineering degrees in two polytechnic schools (Jaén and Linares). A total of 459 students of the bachelor's Engineering degree of the Polytechnic School of Jaén participated in this EPP over three academic years. These were second- and third-year students who were attending disciplines of the Materials Science and Metallurgical Engineering area (Materials Science and Engineering or Materials Technology). Of the total sample, $81.52 \%$ were men and $18.48 \%$ women. A total of $85.87 \%$ were between 20 and 24 years old and $14.13 \%$ between 25 and 35 years old. Only $15.22 \%$ of the participants were occasionally working while they were studying at university. To learn more about the participants, the questionnaire included questions about their ideal job; $43.61 \%$ stated that they wanted to start a business alone or with partners.

\subsection{Hypothesis Analysis}

For each hypothesis, the results were analyzed by applying a simple slope analysis. For Hypothesis 1 , the perception that students have of the environment (PE) has a great impact on the motivation to undertake (MO), it can be seen in Figure 2 that there is a very significant relationship between PE and $\mathrm{MO}$, so Hypothesis 1 is confirmed. 


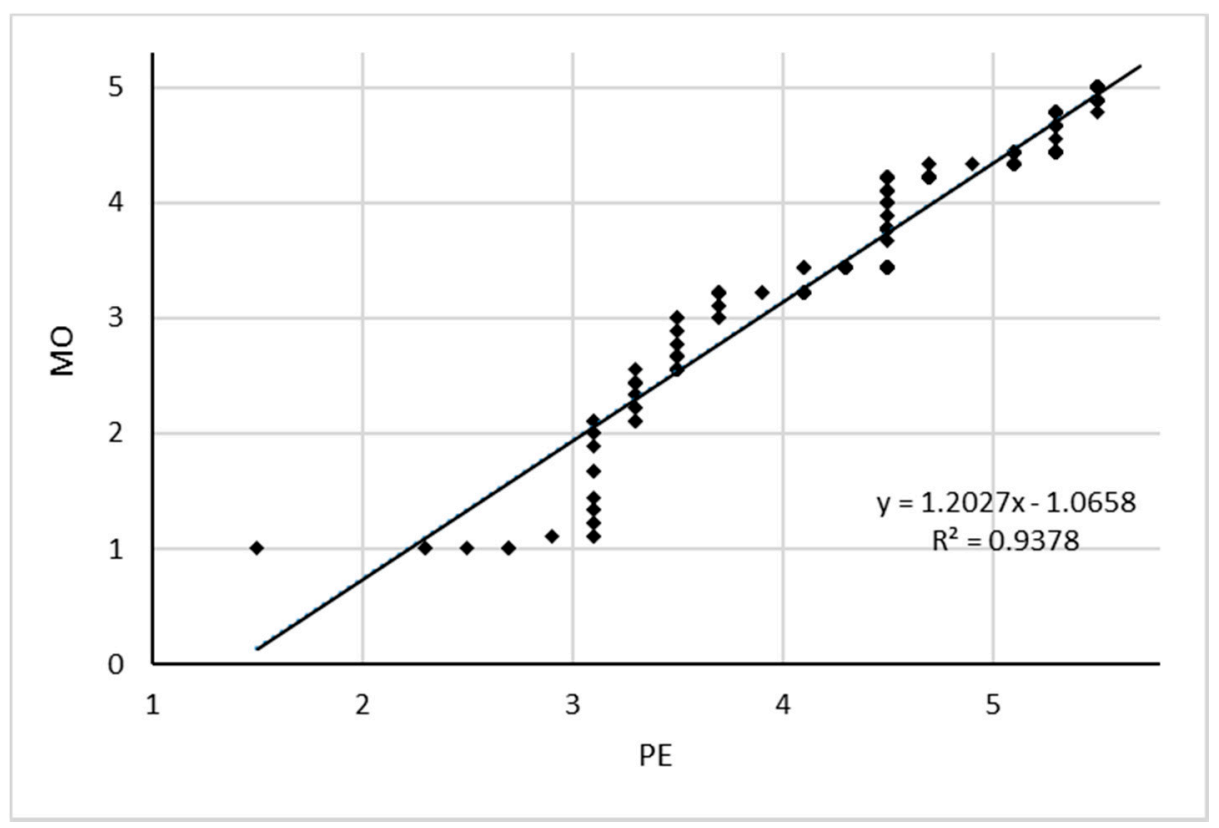

Figure 2. Correlation between Motivation (MO) and Perception of the Environment (PE).

Figure 3 shows that there is a positive relationship between the personal characteristics that the student believes are important to undertake (PR) and the motivation (MO), so Hypothesis 2 is also confirmed.

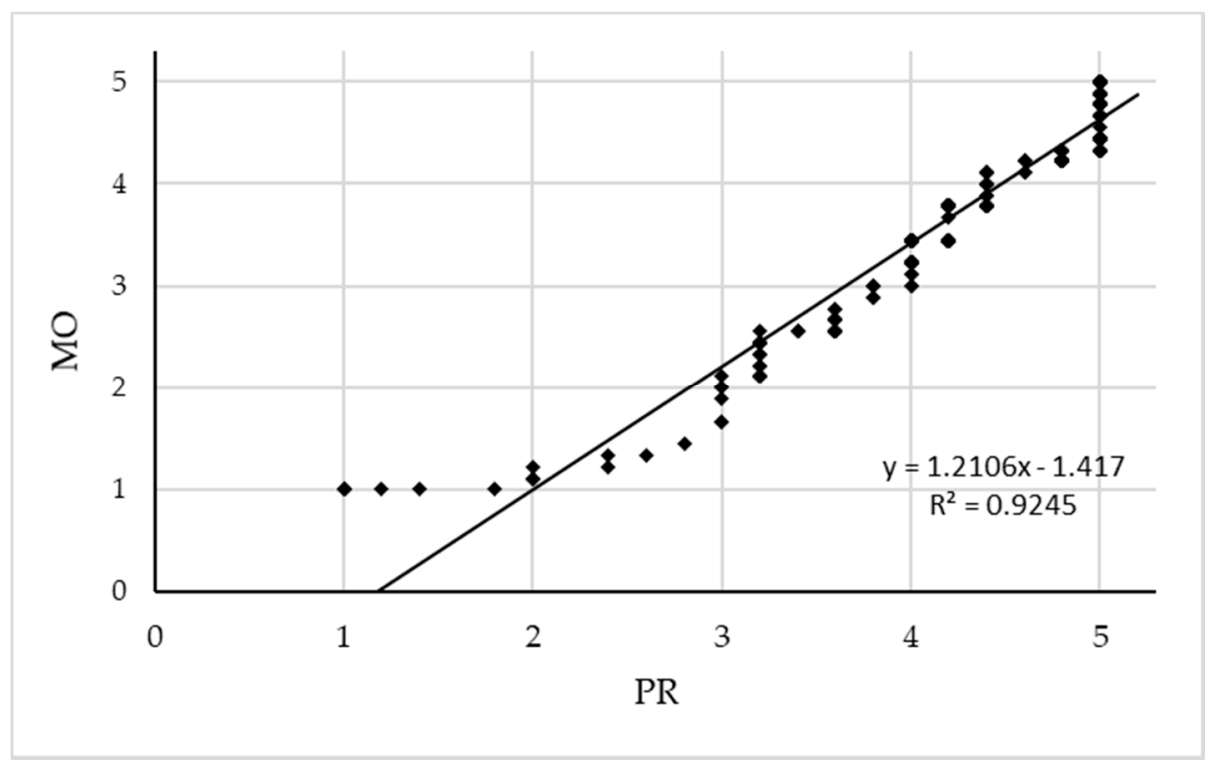

Figure 3. Correlation between Motivation (MO) and Personal Requirements (PR).

After considering the results, it is appreciated that the perception of personal characteristics influences motivation, as many authors have reported [40,41]. Likewise, for the environment and the perception of it. On the one hand, the personal support of the future entrepreneur also has an influence, and on the other hand, the environment in which it operates. That is, aspects such as the economic situation of the region, knowing that there are incentive plans and support for entrepreneurs, a good image of entrepreneurs, and reference to successful or respected entrepreneurs influence the motivation [42-45]. Therefore, working on these two aspects, personal characteristics and environment, could influence the reasons for undertaking and therefore the motivation. 
The activities proposed in this work to achieve the objectives of the EPP and the skills related to entrepreneurship and sustainability, aimed to provide the students with the knowledge about the public and private institutions that have services and resources to entrepreneurship and the details of the aids, grants and resources they offer. These activities should affect the perception of the environment and therefore the entrepreneurial motivation. In addition, meetings with entrepreneurs related to companies committed to the environment were scheduled so that the students learned first-hand the personality of the entrepreneurs. This way, the students could identify the characteristics that are important to being an entrepreneur in themselves. Therefore, these meetings aimed at identifying the personal characteristics that are important to undertake and that can influence motivation, as well as the commitment to the environment acquired by companies.

\subsection{Use of Social Networks and Activities Monitoring}

From the results of the questionnaire about the use of the social networks (Appendix B), the most widely used social networks are Facebook (27.86\%), YouTube (25.95\%), Instagram (17.94\%), Twitter $(16.41 \%)$, Google+ $(5.34 \%)$, Pinterest $(1.91 \%)$, LinkedIn $(1.91 \%)$, and others $(2.67 \%)$. Regarding the frequency of the use of Facebook, $65.12 \%$ of the students use it daily, while $27.91 \%$ periodically. A total of $43.02 \%$ of the participants have more than 180 friends on Facebook and their main use of the social network $(50 \%)$ is for contact with friends. Regarding the actions that they carry out on the social network, $35.03 \%$ share links, files, photos or videos; other actions are: watching videos $(17.88 \%)$, browsing $(14.60 \%)$, making comments $(10.95 \%)$, chat $(4.74 \%)$, tag $(3.65 \%)$, send private messages $(2.92 \%)$, update their profile $(2.92 \%)$, among others.

Facebook and Twitter were the social networks used in this study. Facebook has been used throughout the period of the EPP activities, but its use was outside the classroom. On the contrary, Twitter, has been used in a timely manner to receive immediate feedback from students about the presential activities in the classroom.

On Facebook, the students were asked to search and share links, files and news about the following topics:

- What is necessary to be an entrepreneur?

- Recommendations, suggestions, aids, grants, programs, courses, public and/or private initiatives to promote entrepreneurship.

- To search for an entrepreneur.

- To learn about sustainable business ideas.

The results obtained from the Grytics software indicated that the number of active participants were 172 (more than two posts) in the total period. In relation to the group activity, the average number per course of posts was 274, comments 66 and reactions to posts 2503 . In relation to the post, a wide vision of all the messages was obtained, and the participation generated by the members with each message. The students highlighted in all the posts related to new business ideas and sustainable entrepreneurship. In this sense, issues related to environmental sustainability, such as valorization of waste, recycling of materials, environmental impact, circular economy, zero waste, ecological manufacturing, or clean and renewable energy, have been widely included. On the other hand, other issues related to social sustainability, responsible consumption, and social inclusion have also been included, but to a lesser extent. Table 6 shows the data and characteristics of the posts by academic year. 
Table 6. Posts characteristics.

\begin{tabular}{ccc}
\hline \multirow{2}{*}{ Posts Types } & \multicolumn{1}{c}{ Status } & $14 \%$ \\
\cline { 2 - 3 } & Links & $81 \%$ \\
\cline { 2 - 3 } & Videos/photos & $5 \%$ \\
\hline \multirow{2}{*}{ Posts commented or reacted } & Posts commented $(\mathrm{PC})$ & $14.96 \%$ \\
\cline { 2 - 3 } Reactions types associated to the posts & Posts reacted (PR) & $93.25 \%$ \\
\cline { 2 - 3 } & \multicolumn{2}{c}{ Shares } \\
\cline { 2 - 3 } & \multicolumn{2}{c}{ Likes } \\
\hline Posts engagement score $(2(\mathrm{PC}+\mathrm{PR}) / \mathrm{P})$ & \multicolumn{2}{c}{2.16} \\
\hline
\end{tabular}

On the basis of these data, the average group activity per course (number of posts + number of reactions + number of shares)/number of days (120 days) is 23.84. The group statistics reveal that the group engagement, which gives us the measure of group activity, is 20.86 and the engagement rate is $6.07 \%$. This last result is positive since it is greater than $1 \%$, a value that Facebook considers to be above the average, and indicates that the messages and the issues are attractive to the members of the group. These data are relevant because the group is related to educational purposes and not for leisure.

Another aspect worth considering is related to the period of the greatest activity of the group, which was more intense when students were connected from home, on weekends or during academic holidays. In each course, the best "likes", the most influential members and the least influential members could be established at the end of the Facebook activities. This information was made visible in the group itself in recognition of the students' work.

During the activities in which Twitter was used, only $30 \%$ of the students generated tweets with a different nature: reporting the activity (33\%), giving opinion (14\%), highlighting conclusions $(23 \%)$ and evaluating the activity (30\%). Although the number of tweets was very small compared to the number of students, most of them were very useful because the students used them to evaluate the activity. The students, after this activity, identified the personal requirements in the entrepreneurs that in order of importance would be perseverance/optimism, self-confidence, organizer, creative, innovative, predictive and non-conformist, and commitment to the environment. The global activity was positively evaluated as innovative, original, engaging, and fun.

\subsection{Temporary Study}

Once the activities were completed, the entrepreneurship questionnaire was again carried out (Appendix A). The results of the questionnaire were compared at two different points in time, before (1) and after (2) the activities of the EPP and the use of Facebook and Twitter. The Wilcoxon test was used to assess whether differences existed. The Table 7 shows the results.

Table 7. Results of the Wilcoxon test.

\begin{tabular}{cccc}
\hline \multicolumn{4}{c}{ Paired Sample Statistics } \\
\hline & Factors & $\mathbf{Z}$ & Sig. (Bilateral) \\
\hline PAIR 1 & MO1-MO2 & $-1.568^{\mathrm{b}}$ & 0.011 \\
PAIR 2 & PR1-PR2 & $-0.151^{\mathrm{b}}$ & 0.140 \\
PAIR 3 & PE1-PE2 & $-1.475^{\mathrm{b}}$ & 0.008 \\
\hline
\end{tabular}

b. Based on positive ranks. MO1-MO2: Difference between the motivation factor before and after the activities. PR1-PR2: Difference between the personal requirement factor before and after the activities. PE1-PE2: Difference between the perception of the environment factor before and after the activities. 
The difference between the motivation factor at the beginning of the course and at the end of the course is significant (MO1-MO2). Similar results were observed with the perception of the environment factor (PE1-PE2). However, no significant different existed with the personality requirement factor (PR1-PR2).

With the aforementioned results, it can be affirmed that the activities had a significant impact on the perception of the environment and motivation to undertake, so Hypothesis 3 was confirmed. Similar impacts of the EPP on the factors that influence undertaking were reported in literature. In particular, if the entrepreneurship programs aimed at students who had a positive perception of the environment or high level of self-efficacy, there was a positive effect on the motivation and entrepreneur intention [45].

However, these activities had little influence on the personality requirements. The students identified in the meetings with entrepreneurs that the personality requirements of an entrepreneur should be perseverance/optimism, self-confidence, organizer, creative, innovative, predictive and non-conformist. The data obtained showed that students consider that entrepreneurship programs cannot help to identify if they have the personality requirements to start a business. However, as reported by other authors, when entrepreneurship activities act on motivation, entrepreneurs can be "made" due to the training [45].

\section{Discussion}

This study contributes in different ways to the acquisition of entrepreneurship and sustainability competencies in engineering students. First of all, it is appreciated that entrepreneurship programs affected motivation and therefore students can be trained in entrepreneurship. These results show that due to the training of the students, they would like become entrepreneurs. In this sense, training in entrepreneurship could be a great tool to change society. These findings are similar to other studies. In this sense, many authors point out that when people attend entrepreneurship programs, they perceive entrepreneurship as a more favorable professional option [40,64]. However, the effect of the entrepreneurial education is not clarified, and some authors consider that have negative effects on entrepreneurial intention [65]. This could occur when the programs are focused only on one of the factors that affect the entrepreneurial motivation and do not consider others.

This work also shows that the personal requirements and the perception of the environment greatly affected the motivation to undertake. This is in accordance with other studies $[40,64,66]$ which consider that entrepreneurial programs increase self-efficacy by helping to identify and internalize skills. Mau et al. [66] explain that the increase of the self-confidence makes the people accept greater challenges. However, Díaz-García et al. [57] consider that focusing entrepreneurship promotion programs on activities based only on the self-efficacy does not give good results over time. If no more factors are considered, the entrepreneurial intention decreases.

Consistent with other leading articles, our study shows that, the perception of the environment is a key factor in entrepreneur motivation. In this regard, some studies have provided evidence of the direct effect of the environment on entrepreneurial motivation. Trivedi [67] indicated that a positive university environment and support would help students gain various tangible (finance, knowledge, etc.) and intangible (motivation, self-confidence, awareness of related regulation) resources and a set of skills that result in increased entrepreneurial intention. On the other hand, Asimakopoulos et al. [45] also indicated that social norms have a positive moderating effect on the relationship between entrepreneurial self-efficacy and the entrepreneurial intention of engineering students. Therefore, the perception of the environment is one of the most influential factors when students participate in an entrepreneurship promotion program.

On the other hand, in this study, the approach of the activities and the diffusion way using social networks influenced students positively. The activities modified the way in which the students see the environment since they have been informed about plans and help to undertake, and examples of, successful ideas. 
Social networks have allowed students to work on skills in a continuous and asynchronous way due to the accessibility of information and the tools used. Active involvement has been achieved by the students reaching an engagement rate of $6.07 \%$ in the Facebook group. This fact confirms that the students felt comfortable with the activity of the group and they were actively involved in it.

However, it has been found that the personal characteristics that the students consider important for entrepreneurship were been influenced by the Entrepreneurship Promotion Programs. This may be due to the fact that the main activities related to these aspects were face-to-face and their support and drive through social networks was lesser. Therefore, the role of social networks to transmit and share information and reach out to young people is reinforced, as it leads to more successful results.

In this study, it is perceived that students are very sensitive to the information they receive through social networks since they are a generation that uses these tools every day. Therefore, it can be considered that the use of these tools in programs from other universities can give similar results, as they are tools for global use and without space-time barriers.

Regarding the sustainability competence, the students were able to identify aspects related to environmental sustainability in their internet searches. In all the companies, projects, and ideas, aspects related to the valorization of waste, recycling materials, environmental impact, circular economy, zero waste, ecological manufacturing, or clean and renewable energies have been highlighted. That is, concepts closely related to their knowledge as engineering students and to the disciplines in which the entrepreneurship program has been developed. Environmental sustainability was recognized as a very positive label for many activities or projects. However, it has been detected that aspects related to sustainability from an economic or social perspective were not easily recognized in the searches. Therefore, in future projects it is necessary to influence these social or economic aspects that generate a positive impact on entrepreneurial ideas and projects.

In addition, it should be pointed out that it is difficult to assess whether the students have acquired the sustainability competence or if they have been sensitized on this topic. Sustainability is closely related to the environment, but it is also a personal belief or a lifestyle. Considering that, this competence had a great presence on Facebook during this study and the positive influence of the activities on the perception of the environment, it can be considered that this competence has been acquired by the students. However, we should work towards its incorporation as a personal belief so that in the future entrepreneurship will not be understood without being carried out in a sustainable way.

Governments and universities are concerned about adverse work situations and are betting on initiatives that promote training and encourage the sustainable entrepreneurial spirit of young people. The findings of this study can be used by universities and educational institutions to design entrepreneurship promotion programs, create support systems for entrepreneurship, and work to become an entrepreneurial university with the support of social networks and new technologies. These tools are a great means of acquiring skills.

\section{Conclusions}

In this study, the impact of Entrepreneurship Promotion Programs and social networks on the sustainability entrepreneurial spirit of engineering students have been analyzed. For this, the results obtained in the promotion of entrepreneurship were analyzed before and after developing presential and online activities during three academic years.

The significant factors that influence engineering students to become entrepreneurs are motivation $(\mathrm{MO})$, personal requirements (PR), and perception of the environment (PE); academic and business training (BR) was a non-significant factor according to the statistical study carried out using the KMO test.

The results indicate that the perception of the environment (PE) and the personal requirements (PR), from the perspective of the students, have positive influences on motivation (MO). The perception of the environment factor was positively influenced by the EPP activities developed. Those activities 
were centered on the information about, plans and aids to undertake, and examples of sustainability ideas. All those issues were actively promoted using the social networks.

The personal requirement factor (PR) also influences positively on the motivation (MO). However, the EPP activities had no influence on the PR factor. In our opinion, the meetings with the entrepreneurs had a timely impact on the students and they were lesser promoted on the social networks. In addition, the online activities were mainly focused on the perception of the environment, so the different impact of the EPP on the factors can be attributed to the use of the social networks.

Finally, it is found that the Entrepreneurship Promotion Programs had a positive influence on sustainable entrepreneurial motivation. However, the use of social networks has been crucial to obtain good results. Facebook has contributed to the active participation of the students, with high amount of comments, links, websites, files, or videos. This tool, associated with people's free time, has allowed the students to assimilate information in an easier way with no space-time barriers and during a continuous period of time. The use of Facebook as tool for the teaching-learning process has highlighted its immediacy and the continuous updating of information.

Author Contributions: M.D.L.R., D.E.-Q. and C.R.-C. designed the study, developed the questionnaire (A) and wrote the manuscript. J.D.A.-P. and G.J.-C. developed the social networks questionnaire (B), collected data and analyzed the data. All authors have read and agreed to the published version of the manuscript.

Funding: This research was funded by Vice-Rector's Office for Knowledge Transfer, Employability and Entrepreneurship of the University of Jaén by the project "Management of digital tools aimed at promoting entrepreneurship" and the APC was funded by the University of Jaén.

Conflicts of Interest: The authors declare no conflict of interest.

\section{Appendix A. Questionnaire-Entrepreneurship}

\section{Demographic Data}

1. Gender:

$\square \quad$ Male

$\square \quad$ Female

3. Do you carry out any paid work activity?

Yes

$\square \quad$ No
2. Age:

$\square \quad$ Between 20-24

$\square \quad$ Between 25-35

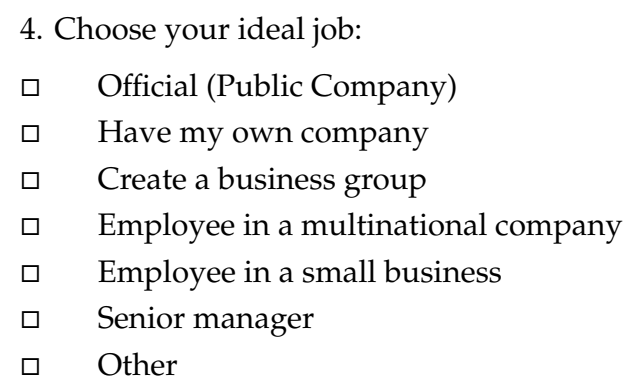

\section{Motivation (MO)}

5. Do you consider the following variables are motivating to be entrepreneur?

5. Totally agree 4. In agreement 3. Indifferent 2. In disagreement 1 . Strongly disagree 


\begin{tabular}{llllll}
\hline & $\mathbf{1}$ & $\mathbf{2}$ & $\mathbf{3}$ & $\mathbf{4}$ & $\mathbf{5}$ \\
\hline Achieve economic independence & $\square$ & $\square$ & $\square$ & $\square$ & $\square$ \\
Personal development & $\square$ & $\square$ & $\square$ & $\square$ & $\square$ \\
Labor independence & $\square$ & $\square$ & $\square$ & $\square$ & $\square$ \\
Working on what interests you & $\square$ & $\square$ & $\square$ & $\square$ & $\square$ \\
Managing one's own time & $\square$ & $\square$ & $\square$ & $\square$ & $\square$ \\
Need & $\square$ & $\square$ & $\square$ & $\square$ & $\square$ \\
The challenge of starting a business & $\square$ & $\square$ & $\square$ & $\square$ & $\square$ \\
I have the monetary capital & $\square$ & $\square$ & $\square$ & $\square$ & $\square$ \\
Higher income & $\square$ & $\square$ & $\square$ & $\square$ & $\square$ \\
\hline
\end{tabular}

\section{Personal Requirements (PR)}

6. What are the personal requirements that you think are essential to be entrepreneur?

5. Totally agree 4. In agreement 3. Indifferent 2. In disagreement 1. Strongly disagree

\begin{tabular}{llllll}
\hline & $\mathbf{1}$ & $\mathbf{2}$ & $\mathbf{3}$ & $\mathbf{4}$ & $\mathbf{5}$ \\
\hline To be creative & $\square$ & $\square$ & $\square$ & $\square$ & $\square$ \\
Organizational capacity & $\square$ & $\square$ & $\square$ & $\square$ & $\square$ \\
Self confidence & $\square$ & $\square$ & $\square$ & $\square$ & $\square$ \\
Take into account all possible situations & $\square$ & $\square$ & $\square$ & $\square$ & $\square$ \\
An original and innovative idea & $\square$ & $\square$ & $\square$ & $\square$ & $\square$ \\
\hline
\end{tabular}

\section{Background Requirements (BR)}

7. How important are the business and academic knowledge to be entrepreneur?

5. Totally agree 4. In agreement 3. Indifferent 2. In disagreement 1. Strongly disagree

\begin{tabular}{llllll}
\hline & $\mathbf{1}$ & $\mathbf{2}$ & $\mathbf{3}$ & $\mathbf{4}$ & $\mathbf{5}$ \\
\hline Business knowledge & $\square$ & $\square$ & $\square$ & $\square$ & $\square$ \\
Academic background & $\square$ & $\square$ & $\square$ & $\square$ & $\square$ \\
\hline
\end{tabular}

\section{Perception of the Environment (PE)}

8. How important are the following items to be entrepreneur?

5. Totally agree 4. In agreement 3. Indifferent 2. In disagreement 1. Strongly disagree

\begin{tabular}{llllll}
\hline & $\mathbf{1}$ & $\mathbf{2}$ & $\mathbf{3}$ & $\mathbf{4}$ & $\mathbf{5}$ \\
\hline Find the right place in the market & $\square$ & $\square$ & $\square$ & $\square$ & $\square$ \\
Economic/financial support & $\square$ & $\square$ & $\square$ & $\square$ & $\square$ \\
Seek advice on the unknown & $\square$ & $\square$ & $\square$ & $\square$ & $\square$ \\
Infrastructure & $\square$ & $\square$ & $\square$ & $\square$ & $\square$ \\
Support from the personal environment & $\square$ & $\square$ & $\square$ & $\square$ & $\square$ \\
\hline
\end{tabular}




\section{Appendix B. Questionnaire-Social Networks}

\begin{tabular}{|c|c|c|}
\hline \multirow{8}{*}{ What social networks do you use? } & $\begin{array}{l}\text { Facebook } \\
\text { Twitter }\end{array}$ & $\begin{array}{l}27.86 \% \\
16.41 \%\end{array}$ \\
\hline & Instagram & $17.94 \%$ \\
\hline & Google+ & $5.34 \%$ \\
\hline & Pinterest & $1.91 \%$ \\
\hline & LinkedIn & $1.91 \%$ \\
\hline & YouTube & $25.95 \%$ \\
\hline & Other & $2.67 \%$ \\
\hline & NA & $0.00 \%$ \\
\hline \multirow{2}{*}{$\begin{array}{c}\text { Did you have a Facebook account before } \\
\text { participating in this project? }\end{array}$} & Yes & $74.42 \%$ \\
\hline & No & $25.58 \%$ \\
\hline \multirow{6}{*}{ How often do you use Facebook? } & More than 10 times a day & $8.14 \%$ \\
\hline & $6-10$ times a day & $19.77 \%$ \\
\hline & $2-5$ times a day & $29.07 \%$ \\
\hline & once a day & $8.14 \%$ \\
\hline & Several times a week & $27.91 \%$ \\
\hline & NA & $6.98 \%$ \\
\hline \multirow{5}{*}{ How many friends do you have on Facebook? } & $1-40$ & $22.09 \%$ \\
\hline & $40-80$ & $10.47 \%$ \\
\hline & $80-140$ & $16.28 \%$ \\
\hline & $140-180$ & $8.14 \%$ \\
\hline & More than 180 & $43.02 \%$ \\
\hline \multirow{6}{*}{ What do you use Facebook for? } & To meet people & $5.26 \%$ \\
\hline & To have contact with my friends & $50.00 \%$ \\
\hline & So people know how life is going for me & $0.88 \%$ \\
\hline & To establish professional relationships & $5.26 \%$ \\
\hline & To flirt & $1.75 \%$ \\
\hline & Other & $36.84 \%$ \\
\hline \multirow{12}{*}{ What do you usually do on Facebook? } & Connect and navigate & $14.60 \%$ \\
\hline & Update my profile & $2.92 \%$ \\
\hline & Share photos and / or videos & $14.96 \%$ \\
\hline & Tag photos and / or videos & $3.65 \%$ \\
\hline & Comment & $10.95 \%$ \\
\hline & Share news, links ... & $20.07 \%$ \\
\hline & Watch videos & $17.88 \%$ \\
\hline & Chat & $4.74 \%$ \\
\hline & Send private messages & $2.92 \%$ \\
\hline & Play online games & $1.09 \%$ \\
\hline & Other & $4.01 \%$ \\
\hline & NA & $2.19 \%$ \\
\hline
\end{tabular}

\section{References}

1. European Commission. Rethinking Education: Investing in skills for better socio-economic outcomes. 2012. Available online: http://eur-lex.europa.eu/ (accessed on 15 February 2020).

2. Kot, S.; Ślusarczyk, B. Problems in the development of higher education in Poland. World Trans. Eng. Technol. Educ. 2014, 12, 675-680.

3. Ulewicz, R. Application of servqual method for evaluation of quality of educational services at the University of Higher Education. Pol. J. Manag. Stud. 2014, 9, 254-264.

4. Laguna-Sánchez, P.; Abad, P.; de la Fuente-Cabrero, C.; Calero, R. A University training programme for acquiring entrepreneurial and transversal employability skills, a students' assessment. Sustainability 2020, 12, 796. [CrossRef]

5. Thomas, A.S.; Mueller, S.L. A case for comparative entrepreneurship: Assessing the relevance of culture. J. Int. Bus. Stud. 2000, 31, 287-301. [CrossRef]

6. Duval-Couetil, N.; Reed-Rhoads, T.; Haghighi, S. Engineering students and entrepreneurship education: Involvement, attitudes and outcomes. Int. J. Eng. Educ. 2012, 28, 425-435. 
7. Greco, A.; de Jong, G. Sustainable entrepreneurship: Definitions, Themes and Research Gaps. In Working Paper Series 1706-CSE; University of Gronongen: Gronongen, The Netherlands, 2017; Available online: https://www.rug.nl/cf/pdfs/cse/wps6_angela.pdf (accessed on 24 February 2020).

8. La Rubia- García, M.D.; Eliche-Quesada, D.; Rus-Casas, C.; Aguilar-Peña, J.D. The social media networking tools for the promotion of the entrepreneurship. Technol. Appl. Electron. Teach. 2016. [CrossRef]

9. Iglesias-García, M.; Díaz, C.G. Facebook como herramienta educativa en el contexto universitario. Historia $Y$ Comun. Soc. 2014, 19, 379-391. [CrossRef]

10. Espuny, C. Actitudes y expectativas del uso educativo de las redes sociales en los alumnos universitarios. RUSC Rev. De Univ. Y Soc. Del Conoc. 2011, 8, 171-185.

11. Onrubia, J. Las tecnologías de la información y la comunicación como instrumento de apoyo a la innovación de la docencia universitaria. Rev. Interuniv. De Form. Del Profr. 2007, 21, 21-25.

12. García, A. Las redes sociales como herramientas para el aprendizaje colaborativo: Una experiencia con Facebook. Re-Presentaciones: Periodis. Comun. Y Soc. 2009, 5, 49-59.

13. Cort, V.D.; Lavazzi, A.; D'Andrea, C. Customer involvement through social media: The cases of some telecommunication firms. J. Open Innov. Technol. Mark. Complex. 2015, 1, 10. [CrossRef]

14. Felix, R.; Rauschnabel, P.A.; Hinsch, C. Elements of strategic social media marketing: A holistic framework. J. Bus. Res. 2017, 70, 118-126. [CrossRef]

15. Park, J.Y.; Sung, C.S.; Im, I. Does social media use influence entrepreneurial opportunity? A review of its moderating role. Sustainability 2017, 9, 1593. [CrossRef]

16. McGee, J.E.; Peterson, M.; Mueller, S.L.; Sequeira, J.M. Entrepreneurial self-efficacy: Refining the measure. Entrep. Theory Pract. 2009, 18, 965-988. [CrossRef]

17. Carter, N.M.; Gartner, W.B.; Shaver, K.G.; Gatewood, E.J. The career reasons of nascent entrepreneurs. J. Bus. Ventur. 2003, 18, 13-39. [CrossRef]

18. Reynolds, P.D.; Carter, N.M.; Gartner, W.B.; Greene, P.G. The prevalence of nascent entrepreneurs in the United States: Evidence from the panel study of entrepreneurial dynamics. Small Bus. Econ. Group 2004, 23, 263-284. [CrossRef]

19. Rotefoss, B.; Kolvereid, L. Aspiring, nascent and fledgling entrepreneurs: An investigation of the business start-up process. Entrep. Reg. Dev. 2005, 17, 109-127. [CrossRef]

20. Standish-Kuon, T.; Rice, M.P. Introducing engineering and science students to entrepreneurship: Models and influential factors at six American universities. J. Eng. Educ. 2002, 91, 33-39. [CrossRef]

21. Bird, B. Implementing entrepreneurial ideas: The case for intention. Acad. Manag. Rev. 1988, 13, 442-453. [CrossRef]

22. Kolvereid, L. Prediction of employment status choice intentions. Entrep. Theory Pract. 1996, 21, 47-58. [CrossRef]

23. Krueger, N.F., Jr.; Brazeal, D.V. Entrepreneurial potential and potential entrepreneurs. Entrep. Theory Pract. 1994, 18, 91-104. [CrossRef]

24. Krueger, N.F.; Reilly, M.D.; Carsrud, A.L. Competing models of entrepreneurial intentions. J. Bus. Ventur. 2000, 15, 411-432. [CrossRef]

25. de Martino, R.; Barbato, R. An analysis of the motivational factors of intending entrepreneurs. J. Small Bus. Strat. 2002, 13, 26-36.

26. Spencer, J.W.; Gómez, C. The relationship among national institutional structures, economic factors, and domestic entrepreneurial activity: A multi-country study. J. Bus. Res. 2004, 57, 1098-1107. [CrossRef]

27. Liñán, F.; Chen, Y.-W. Development and cross-cultural application of a specific instrument to measure entrepreneurial intentions. Entrep. Theory Pract. 2009, 33, 593-617. [CrossRef]

28. Blackburn, R.; Kovalainen, A. Researching small firms and entrepreneurship: Past, present and future. Int. J. Manag. Rev. 2009, 11, 127-148. [CrossRef]

29. Miller, D. A downside to the entrepreneurial personality? Entrep. Theory Pract. 2015, 39, 1-8. [CrossRef]

30. Romero-Martínez, A.M.; Milone, M. Entrepreneurship in Spain: Entrepreneurial intention, motivations and obstacles. Glob. Compet. Gov. 2016, 10, 95-109.

31. Maslow, A. Motivation and Personality, 3rd ed.; Harper \& Row: New York, NY, USA, 1987.

32. Ajzen, I. The theory of planned behavior. Organ. Behav. Hum. Decis. Process. 1991, 50, 179-211. [CrossRef]

33. Shapero, A.; Sokol, L. The social dimensions of entrepreneurship. In Encyclopedia of Entrepreneurship; Prentice-Hall: Englewood Clis, NJ, USA, 1982; pp. 72-90. 
34. Coduras, A. La motivación para emprender en España. Ekonomiaz 2006, 62, 12-39.

35. Uhlaner, L.; Thurik, R. Postmaterialism influencing total entrepreneurial activity across nations. J. Evol. Econ. 2007, 17, 161-185. [CrossRef]

36. Barbosa, S.D.; Gerhardt, M.W.; Kickul, J.R. The role of cognitive style and risk preference on entrepreneurial self-efficacy and entrepreneurial intentions. J. Leadersh. Organ. Stud. 2007, 13, 86-104. [CrossRef]

37. Boyd, N.G.; Vozikis, G.S. The influence of self-efficacy on the development of entrepreneurial intentions and actions. Entrep. Theory Pr. 1994, 18, 63-77. [CrossRef]

38. Zhao, H.; Seibert, S.E.; Hills, G.E. The mediating role of self-efficacy in the development of entrepreneurial intentions. J. Appl. Psychol. 2005, 90, 1265-1272. [CrossRef]

39. Markman, G.D.; Balkin, D.; Baron, R.A. Inventors and new venture formation: The effects of general self-efficacy and regretful thinking. Entrep. Theory Pr. 2002, 27, 149-165. [CrossRef]

40. Chen, C.C.; Green, P.G.; Crick, A. Does entreprenurial self-efficacy distinguish entrepreneurs from managers? J. Bus. Ventur. 1998, 13, 295-316. [CrossRef]

41. de Noble, A.; Jung, D.; Ehrlich, S. Entrepreneurial Self-Efficacy: The Development of a Measure and Its Relationship to Entrepreneurial Actions; Frontiers of Entrepreneurship Research: Waltham, MA, USA, 1999.

42. Florin, J.; Karri, R.; Rossiter, N. Fostering entrepreneurial drive in business education: An attitudinal approach. J. Manag. Educ. 2007, 31, 17-42. [CrossRef]

43. Mueller, S.L.; Goic, S. East-West differences in entrepreneurial self-efficacy: Implications for entrepreneurship education in transition economies. Int. J. Entrepren. Educ. 2003, 1, 613-632.

44. Štefko, R.; Fedorko, R.; Bačík, R. Website content quality in terms of perceived image of higher education institution. Pol. J. Manag. Stud. 2016, 13, 153-163. [CrossRef]

45. Asimakopoulos, G.; Hernández, V.; Peña Miguel, J. Entrepreneurial intention of engineering students: The role of social norms and entrepreneurial self-efficacy. Sustainability 2019, 11, 4314. [CrossRef]

46. Bjornskov, C.H.; Foss, N.J. Economic freedom and entrepreneurial activity: Some cross-country evidence. Public Choice 2008, 134, 307-328. [CrossRef]

47. Holland, D.V.; Shepherd, D.A. Deciding to persist: Adversity, values, and entrepreneurs 'decision policies. Entrep. Theory Pract. 2013, 37, 331-358. [CrossRef]

48. Criado-Gomis, A.; Cervera-Taulet, A.; Iniesta-Bonillo, M.-A. Sustainable entrepreneurial orientation: A business strategic approach for sustainable development. Sustainability 2017, 9, 1667. [CrossRef]

49. Matzembacher, D.E.; Raudsaar, M.; de Barcellos, M.D.; Mets, T. Sustainable entrepreneurial process: From Idea generation to impact measurement. Sustainability 2019, 11, 5892. [CrossRef]

50. O'Brien, E.; Hamburg, I. A critical review of learning approaches for entrepreneurship education in a contemporary society. Eur. J. Educ. 2019, 54, 525-537. [CrossRef]

51. European Commission. Entrepreneurship Education: A Guide for Educators. 2013. Available online: http://ec.europa.eu/DocsRoom/documents/7465 (accessed on 27 March 2020).

52. Law 14/2013, of September 27th, 2013, to Support Entrepreneurs and their Internationalization. Available online: https://www.boe.es/boe/dias/2013/09/28/pdfs/BOE-A-2013-10074.pdf (accessed on 24 February 2020).

53. Law 3/2018, of May 8th, Andalusia for the Promotion of Entrepreneurial Culture in the Andalusian Public System (BOJA), which approves the Plan for the Promotion of Entrepreneurial Culture in the Andalusian Public System (BOJA n ${ }^{\circ} 137$ of July 14th, 2011). Available online: https://www.juntadeandalucia.es/boja/ 2011/137/d1.pdf (accessed on 1 March 2020).

54. Law 8/2013, of May 28, on Measures to create employment and promote entrepreneurship (BOJA of May 31, 2013). Available online: https://www.juntadeandalucia.es/boja/2013/105/BOJA13-105-00139-9276-01_ 00028122.pdf (accessed on 27 March 2020).

55. Plan of Practical Training for Employability of the University of Jaén. Available online: http://www10.ujaen. es/conocenos/servicios-unidades/uempleo (accessed on 1 March 2020).

56. Plan de Apoyo a la transferencia del Conocimiento, el Emprendimiento y la Empleabilidad (2018-2019). Available online: https://www.ujaen.es/gobierno/vicrel/plan-de-apoyo-la-transferencia-del-conocimiento-laempleabilidad-y-el-emprendimiento (accessed on 1 March 2020).

57. Díaz-García, C.; Sáez-Martínez, F.; Jiménez-Moreno, J. Assessing the impact of the "Entrepreneurs" education programme on participants' entrepreneurial intentions. RUSC. Univ. Knowl. Soc. J. 2015, 12, 17-31. [CrossRef]

58. Redes Sociales y Educación: Hacia Una Innovación Didáctica. Available online: https://www.educaweb. com/publicaciones/monografico/2011/redes-sociales-educacion/ (accessed on 6 March 2020). 
59. Fogg, L.; Derek Baird, D.; Fogg, B.J. Facebook Para Educadores. Available online: http://portaljove.apda.ad/ system/files/facebook_para_educadores.pdf (accessed on 20 March 2020).

60. Viñas, M. 15 Razones Para Empezar a Usar Facebook en el Aula. 2011. Available online: http://www. totemguard.com/aulatotem/2011/08/15-razones-para-empezar-a-usar-facebook-en-el-aula/ (accessed on 27 March 2020).

61. Olanrewaju, A.-S.T.; Hossain, M.A.; Whiteside, N.; Mercieca, P. Social media and entrepreneurship research: A literature review. Int. J. Inform. Manag. 2020, 50, 90-110. [CrossRef]

62. Kaiser, H.F. A second generation little jiffy. Psychometrika 1970, 35, 401-415. [CrossRef]

63. Massey, F.J., Jr. The Kolmogorov-Smirnov Test for goodness of Fit. J. Am. Stat. Assoc. 1951, 46, 68-78. [CrossRef]

64. Wilson, F.; Kickul, J.; Marlino, D. Gender, entrepreneurial self/efficacy, and entrepreneurial career intentions: Implications for entrepreneurship education. Entrep. Theory Pract. 2007, 30, 387-406. [CrossRef]

65. Oosterbeek, H.; Praag, M.; Ijsselstein, A. The impact of entrepreneurship education on entrepreneurship skills and motivation. Eur. Econ. Rev. 2010, 54, 442-454. [CrossRef]

66. Mau, W.-C. Factors that influence persistence in Science and Engineering career aspirations. Career Dev. Q. 2003, 51, 234-243. [CrossRef]

67. Trivedi, R. Does university play a significant role in shaping entrepreneurial intention? A Cross country. Comparative analysis. J. Small Bus. Enterp. Dev. 2016, 23, 790-811. [CrossRef]

(C) 2020 by the authors. Licensee MDPI, Basel, Switzerland. This article is an open access article distributed under the terms and conditions of the Creative Commons Attribution (CC BY) license (http://creativecommons.org/licenses/by/4.0/). 